after RNase pretreatment. For quantitative autoradiography, average optical densities (OD) over the dorsal striatum were measured on X-ray film autoradiographs using an IBAS image analyser (Zeiss Kontron). The measurement field was interactively defined and $512 \times 512$ pixel, 256 grey-level images were generated using a MTI video camera with fixed black level and gain. The background level was subtracted for each section, and mean OD was determined for right and left striata. Five or more sections per mouse were analysed, and results were analysed by the Mann-Whitney $U$-test. Autoradiography binding assays have been described ${ }^{27}$ and used $\left[{ }^{3} \mathrm{H}\right] \mathrm{CGS} 21680$ (NEN; $48.6 \mathrm{Ci} \mathrm{mmol}^{-1}$ ) as ligand and $10 \mu \mathrm{M} \mathrm{NECA} \mathrm{as} \mathrm{competitor.}$

Blood pressure and heart rate. Mice were anaesthetized using halothane inhalation ( $1-2 \%$ in oxygen). The left carotid artery was isolated and a PE-10 tubing catheter was inserted into the artery, secured with silk, and tunnelled subcutaneously to exit at the back of the neck. Mice were allowed to recover from surgery for at least $4 \mathrm{~h}$. The arterial line was connected to a pressure transducer, and blood pressure and heart rate were measured using a computerized data acquisition system. For agonist study, a bolus of CGS $21680\left(1 \mathrm{mg} \mathrm{kg}^{-1}\right)$ was administered through the arterial catheter.

Platelet aggregation. Blood was collected by cardiac puncture on sodium citrate $(0.38 \%)$ and pooled from about 10 mice. Platelet-rich plasma was prepared by centrifugation and adjusted to $1.7510^{8} \mathrm{ml}^{-1}$. Platelets were aggregated using a platelet-aggregation profiler (model PAP-4; Bio Data). Platelet-rich plasma $(100 \mu \mathrm{l})$ was incubated for $5 \mathrm{~min}$ in siliconized cuvettes at $37^{\circ} \mathrm{C}$, and aggregation initiated by addition of $5 \mu \mathrm{M}$ ADP.

Behavioural studies. Male mice were kept on a 7a.m. -7 p.m. light cycle. Exploratory activity (horizontal and vertical) was monitored in the $20 \times 20 \mathrm{~cm}$ arena of a Digiscan actimeter (Omnitech Electronics) during a 60-min period. An elevated plus-maze, with $18 \times 6 \mathrm{~cm}$ arms, was placed $50 \mathrm{~cm}$ above the floor. The mouse was placed at the centre of the maze, with head facing a closed arm. The number of entries, time spent and distance travelled in each arm and central area over a 5-min period was recorded by an automated image analysis system (Videotrack 512 system, Viewpoint). For the black and white compartments test, a $5-\mathrm{cm}$ opening connected the compartments $(32 \times 22 \mathrm{~cm}, 18 \mathrm{~cm}$ height). Mice were placed in the black compartment (head facing a corner). The delay for first entering into the brightly lit white compartment, the time spent in the white compartment, and the number of entries were recorded for $5 \mathrm{~min}$. The hot-plate test has been described ${ }^{28}$; the tail-flick test was done by using a tail-flick apparatus. Two measurements were made on each mouse at 3 and $5 \mathrm{~cm}$ from the tail tip. Aggressive behaviour was assayed by the residentintruder test ${ }^{15}$, with slight modifications. Resident male $\mathrm{A}_{2 \mathrm{a}} \mathrm{R}^{+/+}$and $\mathrm{A}_{2 \mathrm{a}} \mathrm{R}^{-/-}$ mice $(14$ weeks old) were isolated in cages $(27 \times 13 \times 13 \mathrm{~cm})$ without replacement of the litter for the four weeks preceding the test. 8-week-old outbred male CD1 mice, housed eight per cage, were used as intruders. A randomly chosen intruder, used only once in each session, was introduced in the resident cage, and aggressive behaviour recorded during a 5-min period. Statistical analysis. Unless otherwise state, statistical analysis was done by the two-tailed unpaired Student's $t$-test (Instat program, GraphPad Software). The two-tailed non-parametric Mann-Whitney $U$-test was used when variances were not equal among series.

Received 21 April; accepted 5 June 1997

1. Olah, M. E. \& Stiles, G. L. Adenosine receptor subtypes: characterization and therapeutic regulation Annu. Rev. Pharmacol. Toxicol. 35, 581-606 (1995).

2. Libert, F. et al. Selective amplification and cloning of four new members of the $G$ protein-coupled recptor family. Science 244, 569-572 (1989).

3. Maenhaut, C. et al. RDC8 codes for an adenosine $\mathrm{A}_{2}$ receptor with physiological constitutive activity. Biochem. Biophys. Res. Commun. 173, 1169-1178 (1990).

4. Fredholm, B. B. Adenosine, adenosine receptors and the actions of caffeine. Pharmacol. Toxicol. 76, 93-101 (1995).

5. Fink, J. S. et al. Molecular cloning of the rat $A_{2}$ adenosine receptor: selective co-expression with $D_{2}$ dopamine receptors in rat striatum. Mol. Brain. Res. 14, 186-195 (1992).

6. Furlong, T. J., Pierce, K. D., Selbie, L. A. \& Shine, J. Molecular characterization of a human brain adenosine $\mathrm{A}_{2}$ receptor. Mol. Brain Res. 15, 62-66 (1992).

7. Weaver, D. R. $A_{2 \mathrm{a}}$ adenosine receptor gene expression in developing rat brain. Mol. Brain Res. 20, 313 327 (1993)

8. Höpker, V. H., Saffrey, M. J. \& Burnstock, G. The neuritogenic effect of myenteric plexus on striata neurones in co-culture involves nitric oxide. Neuroreport 6, 1153-1156 (1995).

9. Schiffmann, S. N. \& Vanderhaeghen, J. J. Adenosine $A_{2}$ receptors regulate the gene expression of striatopallidal and striatonigral neurons. J. Neurosci. 13, 1080-1087 (1993).

10. Balk, J. H. et al. Parkinsonian-like locomotor impairment in mice lacking dopamine $\mathrm{D}_{2}$ receptors. Nature 377, 424-428 (1995)

11. Grace, A. A. Phasic versus tonic dopamine release and the modulation of dopamine system responsivity: a hypothesis for the etiology of schizophrenia. Neuroscience 41, 1-24 (1991).

12. Nikodijeviç, O., Jacobson, K. A. \& Daly, J. W. Locomotor activity in mice during chronic treatment with caffeine and withdrawal. Pharmacol. Biochem. Behav. 44, 199-216 (1993).

13. File, S. E., Baldwin, H. A., Johnston, A. L. \& Wilks, L. J. Behavioral effects of acute and chronic administration of caffeine in the rat. Pharmacol. Biochem. Behav. 30, 809-815 (1988).

14. Jain, N., Kemp, N., Adeyemo, O., Buchanan, P. \& Stone, T. W. Anxiolytic activity of adenosine receptor activation in mice. Br. J. Pharmacol. 116, 2127-2133 (1995).

15. Saudou, F. et al. Enhanced aggressive behavior in mice lacking 5-HT ${ }_{1 \mathrm{~B}}$ receptor. Science 265, 18751878 (1994).

16. Palmour, R. M., Lipowski, C. J., Simon, C. K. \& Ervin, F. R. Adenosine analogs inhibit fighting in isolated male mice. Life Sci. 44, 1293-1301 (1989).

17. Sawynok, J. \& Yaksh, T. L. Caffeine as an analgesic adjuvant: a review of pharmacology and mechanisms of action. Pharmacol. Rev. 45, 43-85 (1993).

18. Sweeney, M. I., White, T. D., Jhamandas, K. H. \& Sawynok, J. Morphine releases endogenous adenosine from the spinal cord in vivo. Eur. J. Pharmacol. 141, 169-170 (1987).

19. De Lander, G. E. \& Keil, G. J. Antinociception induced by intrathecal coadministration of selective adenosine receptor and selective opioid receptor agonists in mice. J. Pharmacol. Exp. Ther. 268, $943-$ 951 (1994)

20. McQueen, D. S. \& Ribeiro, J. A. Pharmacological characterization of the receptor involved in chemoexcitation induced by adenosine. Br. J. Pharmacol. 88, 615-620 (1986).

21. Cristalli, G. et al. Inhibition of platelet aggregation by adenosine receptor agonists. Naunyn. Schmiedebergs Arch. Pharmacol. 349, 644-650 (1994).

22. Dionisotti, S., Zocchi, C., Varani, K., Borea, P. A. \& Ongini, E. Effects of adenosine derivatives on human and rabbit platelet aggregation. Correlation of adenosine receptor affinities and antiaggregatory activity. Naunyn. Schmiedebergs Arch. Pharmacol. 346, 673-676 (1994).

23. Varani, K., Gessi, S., Dalpiaz, A. \& Borea, P. A. Pharmacological and biochemical characterization of purified $\mathrm{A}_{2 \mathrm{a}}$ adenosine receptors in human platelet membranes by $\left[{ }^{3} \mathrm{H}\right]$-CGS 21680 binding. $\mathrm{Br}$. J. Pharmacol. 117, 1693-1701 (1996).

24. Ongini, E. \& Fredholm, B. B. Pharmacology of adenosine $A_{2 \mathrm{~A}}$ receptors. Trends Pharmacol. Sci. 17, 364-372 (1996).

25. Nagy, A., Rossant, J., Nagy, R., Abramow-Neverly, W. \& Roder, J. C. Derivation of completely cell culture-derived mice from early-passage embryonic stem cells. Proc. Natl Acad. Sci. USA 90, 84248428 (1993).

26. Worst, W. \& Joyner, A. L. in Gene Targeting, a Practical Approach (ed. Joyner, A. L.) 33-61 (Oxford University Press, Oxford, 1993)

27. Schiffmann, S. N. \& Vanderhaeghen, J. J. Ontogeny of gene expression of adenosine $A_{2}$ receptor in the striatum: early localization in the patch compartment. J. Comp. Neurol. 317, 117-128 (1992).

28. Costentin, J. et al. Dissociated effects of inhibitors of enkephalin-metabolising peptidases or naloxone on various nociceptive responses. Eur. J. Pharmacol. 123, 37-44 (1986).

Acknowledgements. The R1 ES and STP cell lines were provided by A. Nagy and B. Colledge, respectively. We thank J.-F. Aubert for his help with the determination ofthe haemodynamic parameters; O. Le Moine, H. Louis, D. Penninck and C. Kucharzewski for discussion; and E. Bressy, M. J. Simons, E. Quertainmont and M. Verslype for technical assistance. This work was supported by the Belgian programme on Interuniversity Poles of Attraction initiated by the Belgian State, Prime Minister's Office, Federal Service for Science, Technology and Culture. It was also supported by the Fonds de la Recherche Scientifique Médicale of Belgium, the BIOMED2 programme, and the Foundation Médicale Reine Elisabeth. Scientific responsiblity belongs to the authors. C.L. and S.N.S. are Chercheurs Qualifiés of the Fonds National de la Recherche Scientifique.

Correspondence and request for materials should be addressed to M.P. (e-mail: mparment@ulb.ac.be). The EMBL/Genbank accession numbers for the mouse $\mathrm{A}_{2 \mathrm{a}} \mathrm{R}$ gene sequences are Y13344, Y13345 and Y13346.

\section{Altered pain perception and inflammatory response in mice lacking prostacyclin receptor}

\section{Takahiko Murata`, Fumitaka Ushikubi, Toshiyuki Matsuoka‘, Masakazu Hirata ${ }^{\star}$, Atsushi Yamasaki $\nmid$, Yukihiko Sugimoto $\nmid$, Atsushi Ichikawa $\nmid$, Yoshiya Aze $\ddagger$, Takashi Tanaka, , Nobuaki Yoshidas, Akinori Ueno\|, Sachiko Oh-ishi\| \& Shuh Narumiya ${ }^{\star}$}

* Department of Pharmacology, Faculty of Medicine, and † Department of Physiological Chemistry, Faculty of Pharmaceutical Sciences, Kyoto University, Sakyo, Kyoto 606-01, Japan

$\ddagger$ Fukui Institute for Safety Research, Ono Pharmaceutical Company, Mikuni, Fukui 913, Japan

$\$$ Division of Molecular and Cellular Immunology, Research Institute Osaka Medical Center for Maternal and Child Health, Izumi, Osaka 590-02, Japan \| Department of Pharmacology, School of Pharmaceutical Sciences, Kitasato University, Shirokane, Tokyo 108, Japan

Prostanoids are a group of bioactive lipids working as local mediators $^{1}$ and include $\mathrm{D}, \mathrm{E}, \mathrm{F}$ and $\mathrm{I}$ types of prostaglandins (PGs) and thromboxanes. Prostacyclin $\left(\mathrm{PGI}_{2}\right)$ acts on platelets and blood vessels to inhibit platelet aggregation and to cause vasodilatation, and is thought to be important for vascular homeostasis ${ }^{2}$. Aspirin-like drugs, including indomethacin, 
which inhibit prostanoid biosynthesis, suppress fever, inflammatory swelling and pain, and interfere with female reproduction, suggesting that prostanoids are involved in these processes ${ }^{1,3}$, although it is not clear which prostanoid is the endogenous mediator of a particular process. Prostanoids act on seven-transmembrane-domain receptors which are selective for each type $e^{4}$. Here we disrupt the gene for the prostacyclin receptor ${ }^{5}$ in mice by using homologous recombination. The receptor-deficient mice are viable, reproductive and normotensive. However, their susceptibility to thrombosis is increased, and their inflammatory and pain responses are reduced to the levels observed in indomethacin-treated wild-type mice. Our results establish that prostacyclin is an antithrombotic agent in vivo and provide evidence for its role as a mediator of inflammation and pain.

We disrupted the mouse gene encoding the prostacyclin receptor (IP) (Fig. 1a) and established two lines of embryonic stem cells.
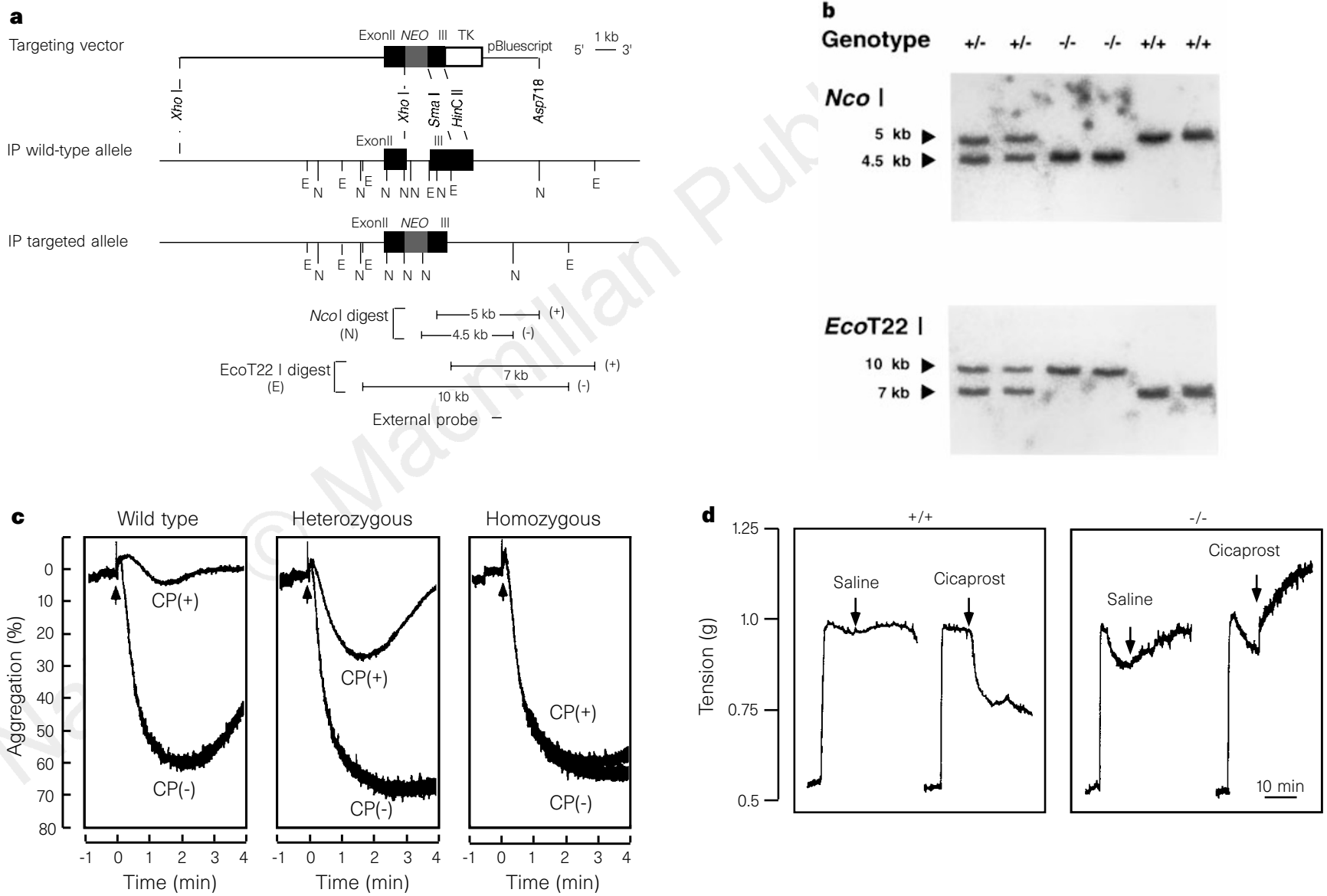

Chimaeric mice were generated from each line. The mice were backcrossed with $\mathrm{C} 57 \mathrm{BL} / 6$ mice and the resulting heterozygous littermates $\left(I P^{+/-}\right)$were bred to produce homozygous mice (Fig. 1b). Breeding of heterozygotes produced homozygous $I P^{-/-}$mice at a rate lower than expected from the mendelian frequency; $30(+/+)$, $72(+/-)$ and $19(-/-)$ males and $48(+/+), 80(+/-)$ and $32(-/-)$ females. This suggests that there may be prenatal mortality in IPdeficient mice, especially in males. A similar abnormal mendelian ratio of male $\mathrm{F}_{2}$ progeny was reported for cyclooxygenase-2-deficient mice ${ }^{6}$. Homozygous mice that survived to birth grew normally, lived longer than one year, and were fertile. No morphological or histological abnormalities were detected. We analysed one line of $I P$ mutant mice in detail.

Loss of the functional IP receptor in $I P^{-1-}$ mice was verified by the inability of a prostacyclin analogue, cicaprost ${ }^{7}$, to inhibit ADP-induced platelet aggregation (Fig. 1c). In addition, aortic b

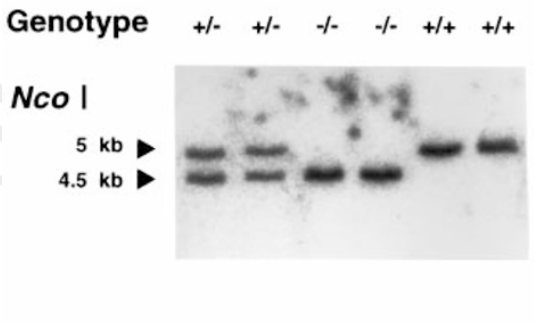

EcoT22 I

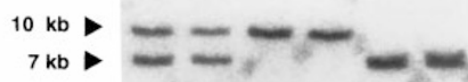

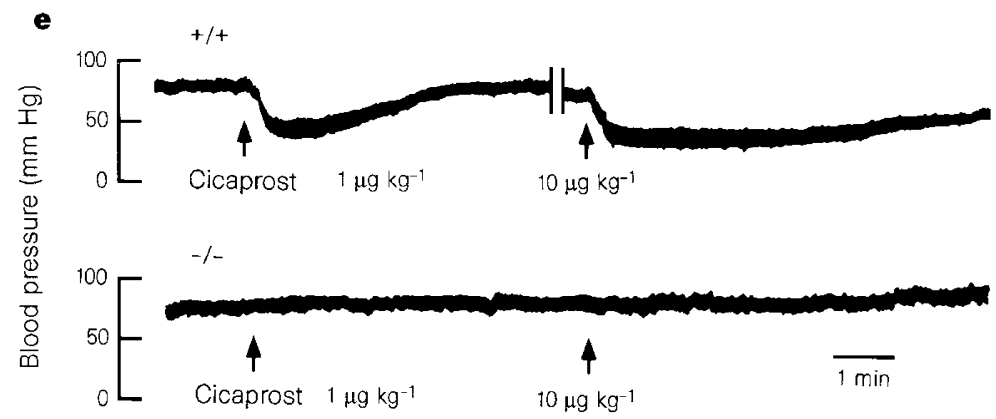

Figure 1 Targeted disruption of the IP gene and loss of the functional receptor. a, Restriction maps for the targeting vector (top), the wild-type IP receptor allele (middle) and the targeted allele (bottom). Exons are shown by closed boxes. NEO, neomycin-resistant gene; $T K$, thymidine kinase gene; $N, N c O l ; E$, EcoT221. b. Southern blot analysis of genomic DNA of heterozygous offspring. Ncol- and EcoT221-digested genomic DNA was hybridized with the external probe as shown in $\mathbf{a} .+/+$, Wild type; +/-, heterozygote; -/-, homozygote. c, Platelet aggregation. Platelet-rich plasma was prepared and pretreated with $(+)$ and without (-) $10 \mathrm{nM}$ cicaprost (CP) for 1 min. Aggregation was initiated by addition of $5 \mu \mathrm{M}$ ADP (arrow) and monitored by following the change in turbidity. $\mathbf{d}$, Relaxation of aortic smooth muscle. The aortic ring from wild-type $(+/+)$ and $/ P^{-/-}$animals was contracted with $0.1 \mu \mathrm{M}$ noradrenaline. The relaxation response to $1 \mu \mathrm{M}$ cicaprost is shown. e, Blood pressure response to cicaprost in wild-type $(+/+)$ (top) and $/ P^{-/-}$(bottom) mice. 


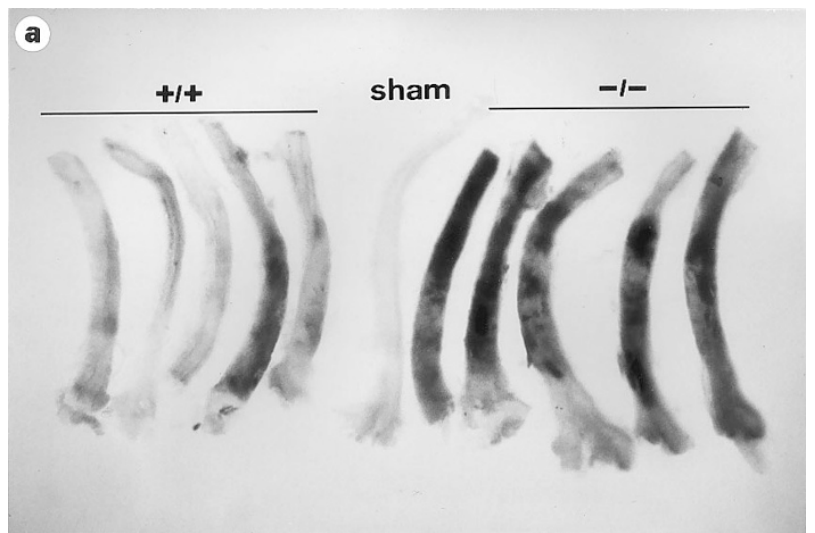

Figure 2 Arterial thrombosis in wild-type and IP-deficient homozygous mice. a, Thrombosis induced by ferric chloride. Five arterial preparations each from wildtype (left) and $I P^{-/-}$mice (right) are shown. Middle, preparation from a shamoperated homozygous animal. b. Thrombotic scores in wild-type $(+/+)($ left) and $I P^{-/-}$(right) mice. Thrombosis was scored as follows: 0 , without apparent

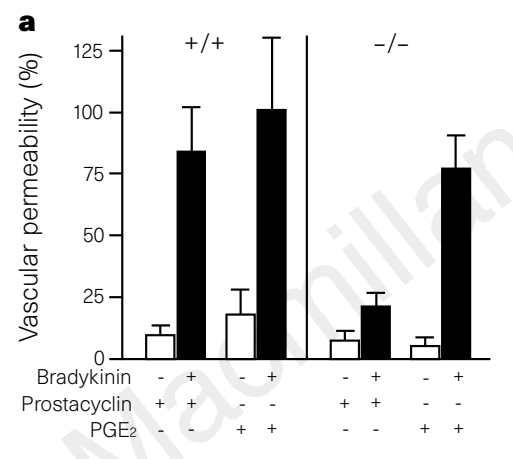

Figure $\mathbf{3}$ Inflammatory responses in IP-deficient mice. a, Vascular permeability to exogenous prostacyclin and $\mathrm{PGE}_{2}$ in wild-type and $/ P^{-/-}$mice. Either prostacyclin $(n=6)$ or $\mathrm{PGE}_{2}(n=5)$ ( $1 \mathrm{nmol}$ of each) was injected intradermally alone or with $0.1 \mathrm{nmol}$ bradykinin. Vascular permeability was examined as described in Methods. b, Carrageenin-induced paw oedema. $30 \mu$ l of $2 \%$ carrageenin was

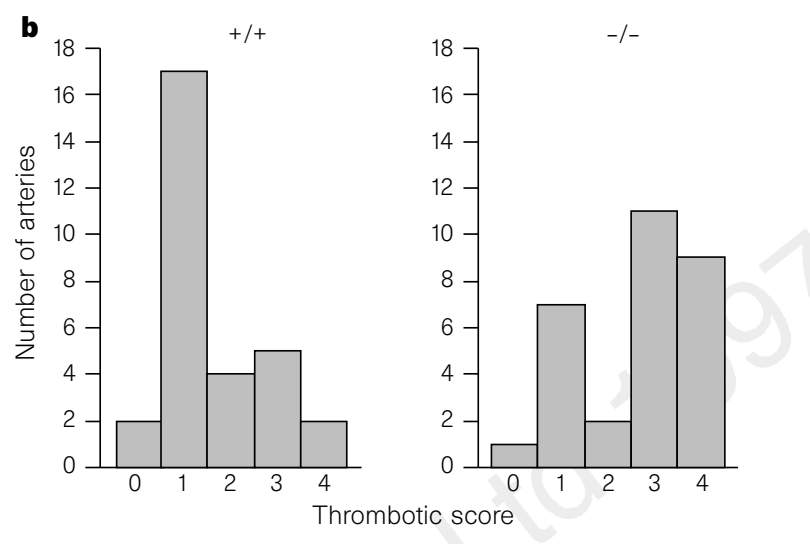

thrombus; 1, small and isolated thrombi; 2, mural thrombi; 3, partially occlusive thrombi; 4, occlusive thrombi. Results from fifteen mice (a total of 30 arteries) are shown for each. There is a significant different at $P<0.01$ between wild-type and $I P^{-/-}$mice by the Mann-Whitney $U$-test.

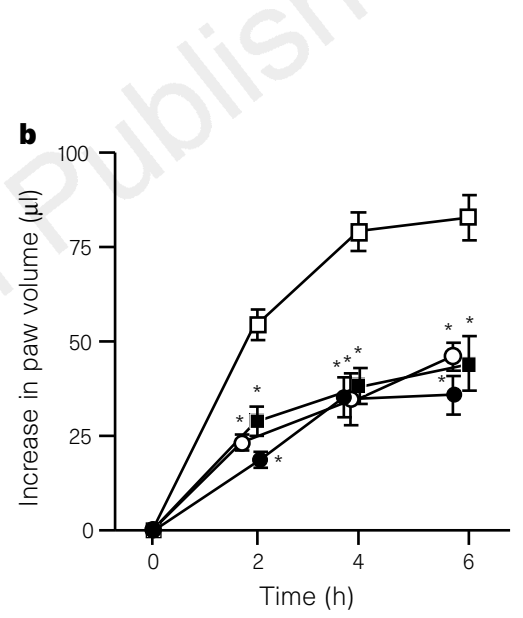

injected into the right hind paw of mice and the increase in paw volume was monitored. Indomethacin (Ind) $\left(10 \mathrm{mg} \mathrm{kg}^{-1}\right)$ was administered intraperitoneally 30 min before carrageenin treatment. White squares, wild-type $(n=9)$; white circles, $I P^{-/-}$mice $(n=10)$; black squares, wild-type mice treated with indometha$\operatorname{cin}(n=8)$; black circles, $I P^{-/-}$mice treated with indomethacin $(n=7) .{ }^{*}, P<0.01$. rings isolated from IP-deficient homozygous mice did not relax in response to cicaprost, although the aorta from wild-type mice did (Fig. 1d). Furthermore, intravenous injection of cicaprost $\left(1 \mu \mathrm{g} \mathrm{kg}^{-1}\right)$ caused hypotension of $\sim 30 \mathrm{~mm} \mathrm{Hg}$ in anaesthetized wild-type mice, whereas there was no change in blood pressure in IP-deficient mice even at a cicaprost dose of $10 \mu \mathrm{g} \mathrm{kg}^{-1}$ (Fig. 1e). On the other hand, intravenous administration of the prostaglandin $\mathrm{PGE}_{2}$ caused transient hypotension in both types of animals; a drop of $24.0 \pm 2.8(n=5)$ and $23.2 \pm 1.7 \mathrm{~mm} \mathrm{Hg}(n=5)$ at $10 \mu \mathrm{g} \mathrm{kg}^{-1}$ of $\mathrm{PGE}_{2}$ for wild-type and IP-deficient mice, respectively. These results verified that specific disruption of the IP receptor had occurred, and further indicate that a single type of IP receptor mediates the actions of prostacyclin in both platelets and vascular smooth muscles. The basal blood pressure and heart rate of IPdeficient mice were identical with those of wild-type mice in the conscious state: the mean blood pressure and heart rate were $88 \pm 3 \mathrm{~mm} \mathrm{Hg}$ and $646 \pm 23$ beats per $\min (n=10)$, and $85 \pm 3 \mathrm{~mm} \mathrm{Hg}$ and $645 \pm 21$ beats per $\min (n=10)$ for wildtype and IP-deficient mice, respectively. The bleeding time in IPdeficient mice was normal, being $87 \pm 10$ and $90 \pm 11 \mathrm{~s}$ for wildtype and $I P^{-/-}$mice, respectively $(n=12$ each). However, when a prostacyclin mimetic, beraprost ${ }^{8}$, was administered per os $\left(3 \mathrm{mg} \mathrm{kg}^{-1}\right)$, it prolonged the bleeding time of wild-type mice $(>10 \mathrm{~min}$; $n=6)$ but not that of IP-deficient mice $(117 \pm 14 \mathrm{~s} ; n=6)$. These results suggest that prostacyclin is not involved in the regulation of heart rate, blood pressure and bleeding under basal conditions. This is in contrast with the findings on another endothelium-derived vasorelaxant, nitric oxide; mice deficient in endothelial nitric oxide synthase are hypertensive under basal conditions ${ }^{9}$.

Endogenous prostacyclin has long been thought to be involved in the prevention of thrombosis and vasospasm ${ }^{2}$. We therefore evaluated the thrombotic tendency of IP-deficient mice. We first confirmed that $I P^{-/-}$mice could synthesize prostacyclin. Isolated aortas from $I P^{-/-}$mice produced $126 \pm 22 \mathrm{pmol}(n=5)$ of prostacyclin, determined as the stable metabolite 6-keto- $\mathrm{PGF}_{1 \alpha}$ that was produced per mg wet weight in $20 \mathrm{~min}$. These levels were similar to those of wild-type mice $(177 \pm 40 \mathrm{pmol} ; n=5)$. The bilateral carotid arteries of wild-type and $I P^{-/-}$mice were then exposed and topically painted with $7.5 \% \mathrm{FeCl}_{3}$ solution, a procedure known to injure the endothelium ${ }^{10}$. Occlusion of the arterial flow and thrombus formation were examined after $4 \mathrm{~h}$. As shown in Fig. 2a, most of the arteries of wild-type mice showed only mural thrombi of yellowish colour. In contrast, about two-thirds showed obstructive 

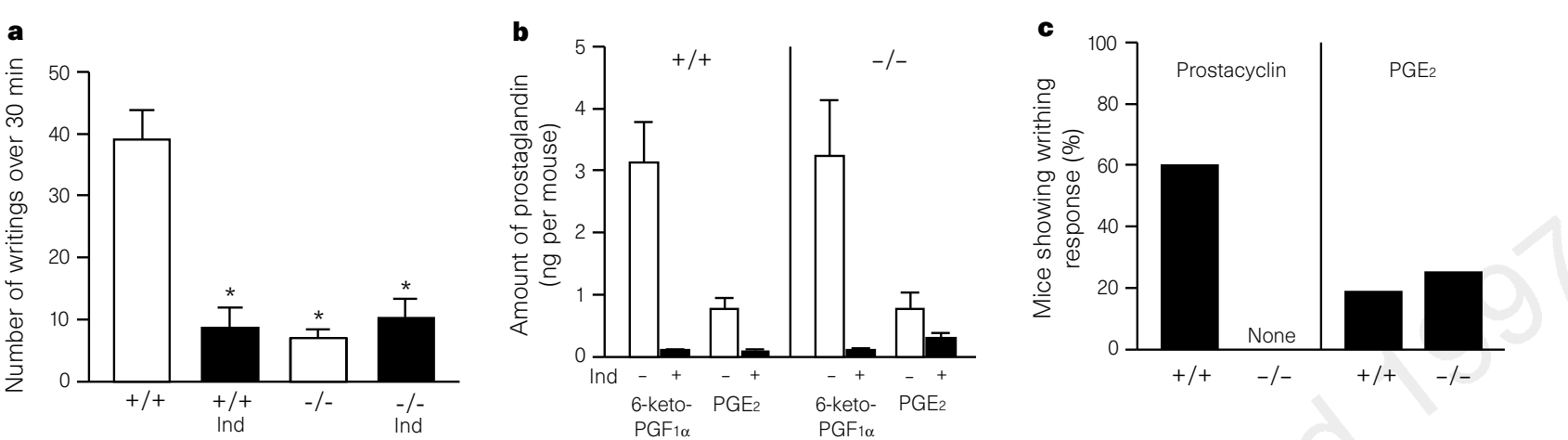

Figure 4 Nociceptive responses in IP-deficient mice. a, Acetic acid writhing. Acetic acid was injected intraperitoneally into wild-type mice $(n=8)$, wild-type mice treated with indomethacin (Ind) $(n=8), I P^{-/-}$mice $(n=9)$ and $I P^{-/-}$mice treated with indomethacin $(n=6)$, and the writhing responses were counted for $30 \mathrm{~min}$. Indomethacin was administered as for Fig. 3. ${ }^{*}, P<0.01$. b, Production of prostacyclin and $\mathrm{PGE}_{2}$ in the peritoneal cavity of mice treated with acetic acid. Diluted acetic acid was injected i.p. and the peritoneal fluid collected after $15 \mathrm{~min}$

thrombi with reddish tails (in $I P^{-/-}$mice) (Fig. 2b). In another experiment monitoring the effects of the $\mathrm{FeCl}_{3}$ treatment for a longer period, $30 \%$ of IP-deficient mice ( 4 out of 12 ) died within 1 day owing to bilateral occlusions of the carotid arteries and/or embolic stroke, whereas the wild-type mice $(n=13)$ all survived this period.

Acute inflammation is characterized by hyperaemia, oedema, leukocyte migration and pain. Prostanoids are thought to contribute to these processes by causing peripheral vasodilation and by sensitizing primary afferents to noxious stimuli ${ }^{3} \mathrm{PGE}_{2}$ has long been regarded as a principal mediator of these processes, although several prostanoids show similar effects ${ }^{11,12}$. We therefore first compared the effects of exogenously added $\mathrm{PGE}_{2}$ and prostacyclin on vascular permeability. As shown in Fig. 3a, both $\mathrm{PGE}_{2}$ and prostacyclin potentiated the bradykinin-induced permeability to a similar extent in wild-type mice; $I P^{-/-}$mice showed a response to $\mathrm{PGE}_{2}$ only. We then examined the role of endogenous prostacyclin in inflammation by applying the carrageenin-induced paw-oedema model $^{13}$ to $I P^{-1-}$ mice. The carrageenin injection caused a timedependent increase in the volume of the injected paw in wild-type animals as a result of oedema (Fig. 3b). This increase is suppressed by $50 \%$ by pretreatment with indomethacin. Unexpectedly, the progress of oedema was reduced in IP-deficient mice to the same extent as in indomethacin-treated animals, indicating that prostacyclin is a major prostanoid eliciting the inflammatory response in this model. The proinflammatory role of prostacyclin was also tested in another model, carrageenin-induced pleurisy ${ }^{14}$, in which carrageenin was injected into the pleural cavity of mice and exudate was collected after $3 \mathrm{~h}$. A significant reduction of the exudate volume was observed in IP-deficient mice $(P<0.05)$ (data not shown).

The role of prostacyclin in inflammatory pain was next examined in IP-deficient mice. Our interest in the involvement of IP in pain originates from our findings that IP receptor messenger RNA is abundantly expressed and coexists with substance-P mRNA in neurons of the dorsal root ganglion ${ }^{15}$. Prostanoids may produce hyperalgesia not only by peripheral sensitization ${ }^{3}$ but also by facilitating pain transmission at the spinal ${ }^{16}$ and supraspinal ${ }^{17}$ levels. IP involvement in the latter mechanisms was tested by the tail-flick method ${ }^{18,19}$ and by the hot-plate test ${ }^{18}$. The latent period before response in both tests was not significantly different in wildtype and IP-deficient mice (data not shown), suggesting that the receptor IP is not involved in nociceptive transmission at the spinal and supraspinal levels. We next used the acetic acid-induced wri- for measuring PGs. Results are means \pm s.e.m. (n was 4-5). Ind, indomethacinpretreatment. c, Writhing responses to exogenous prostacyclin and $P G E_{2} .2 \mu \mathrm{g}$ of each was administered intraperitoneally to wild-type (+/+) and IP-deficient (-/-) mice, and the writhing response was counted in affected animals for $15 \mathrm{~min}$. The numbers of animals used were 20 for prostacyclin injection and 16 for $\mathrm{PGE}_{2}$ injection.

thing test ${ }^{20}$ to examine the involvement of IP in inflammatory pain. Injection of a dilute acetic acid solution intraperitoneally caused about forty writhing responses in wild-type animals; this reaction was significantly reduced by pretreatment with indomethacin (Fig. 4a). Surprisingly, the response of the IP-deficient mice was comparable to that of the indomethacin-pretreated animals and markedly reduced compared to wild-type mice, indicating that IP is involved in this nociceptive response. Under these conditions, acetic acid injection produced similar amounts of prostacyclin in wild-type and $I P^{-1-}$ mice (Fig. 4b). PGE $_{2}$ was also produced, but in about one quarter of the amount of prostacyclin. The same profile for PG production has been reported in the peritoneal cavity of zymosaninjected mice ${ }^{21}$. Because $\mathrm{PGE}_{2}$ may be involved in pain response, we compared the writhing responses to prostacyclin and $\mathrm{PGE}_{2}$ by injecting the same amount of each PG intraperitoneally into these animals (Fig. 4c). Prostacyclin caused the writhing response in $60 \%$ of the wild-type mice and in none of the IP-deficient animals, whereas $\mathrm{PGE}_{2}$ induced the response in less than $25 \%$ animals in both types.

In conclusion, we have established the antithrombotic role of endogenous prostacyclin. As prostacyclin has also been implicated in atherosclerosis and diabetic angiopathy ${ }^{2,22}$, IP-deficient mice may be useful for examining its role in these diseases. Our results indicate that prostacyclin is a mediator of inflammatory swelling and pain. Whether prostacyclin and $\mathrm{PGE}_{2}$ have different, context-dependent roles in these processes is an important issue that could be tested by comparing the response to various stimuli at different sites in IPdeficient mice and in mice deficient in PGE receptors.

\section{Methods}

Gene targeting. Murine IP genomic clones were isolated from a 129/Sv-strain genomic DNA library (Stratagene) by using its $\mathrm{CDNA}^{5}$ as a probe. The targeting vector was constructed by replacing a 2.4 -kb fragment containing parts of the putative exons II and III, which encode the sixth transmembrane domain towards the $\mathrm{C}$ terminus of this seven-transmembrane-domain receptor ${ }^{5}$, with the neomycin-resistance gene (pMC1-neo; Stratagene). The herpes simplex virus thymidine kinase gene $(T K)$ was inserted downstream (Fig. 1a). The targeting vector was linearized with Asp718 and introduced into E14-1 ES cells by electroporation. G418- and gancyclovir-resistant clones were isolated and screened by PCR for homologous recombination, which was then confirmed by Southern blot hybridization. The generation of chimaeras and mutant mice has been described ${ }^{23}$.

Bioassays. Blood was drawn from the heart and mixed with an equal volume of $20 \mathrm{mM}$ HEPES, pH 7.4. Sodium citrate $(0.38 \%)$ was used as anticoagulant. 
Platelet-rich plasma was obtained by centrifugation, and diluted to $5 \times 10^{5}$ platelets per $\mu l$ with plasma. Platelet aggregation was assayed as described ${ }^{7}$. An aortic ring $4 \mathrm{~mm}$ long was prepared from thoracic aorta and mounted on a pair of wires in an organ bath filled with Krebs-Henseleit buffer gassed with $95 \%$ $\mathrm{O}_{2}-5 \% \mathrm{CO}_{2}$ at $37^{\circ} \mathrm{C}$. Preload was $0.5 \mathrm{~g}$. The ring was contracted with $0.1 \mu \mathrm{M}$ noradrenaline and its relaxation response to various concentrations of cicaprost tested.

Blood pressure, heart rate and bleeding time. Basal blood pressure and heart rate were measured in conscious animals by using the tail-cuff method. In the analysis of cicaprost- or $\mathrm{PGE}_{2}$-induced hypotension, animals were anaesthetized with pentobarbital sodium $\left(60 \mathrm{mg} \mathrm{kg}^{-1}\right.$; i.p.), and arterial blood pressure was monitored through a cannula into the carotid artery. Bleeding time was measured as described ${ }^{24}$.

Prostanoid production. Isolated aorta was preincubated in oxygenated Krebs-Henseleit buffer at $37^{\circ} \mathrm{C}$ for $1 \mathrm{~h}$ and then incubated in fresh buffer for $20 \mathrm{~min}$; the supernatant was assayed. Prostanoids in peritoneal lavage were extracted with Sep-Pak C18 columns and then assayed for 6-keto-PGF $F_{1 \alpha}$ and $\mathrm{PGE}_{2}$ (ref. 25).

Analysis of thrombus formation. Mice (24-30 g) were anaesthetized with halothane and the carotid arteries exposed by a cervical incision. A piece of Parafilm $1 \mathrm{~mm}$ wide was inserted under the artery and $5 \mu \mathrm{l}$ of a $7.5 \% \mathrm{FeCl}_{3}$ solution was dropped on the artery ${ }^{10}$. After $1 \mathrm{~min}$ the solution was wiped off, and the mice were allowed to recover from the anaesthetic. After $4 \mathrm{~h}$, the arteries and blood flow were examined microscopically by cutting the distal end of the artery. A 5-mm long segment containing the affected region was excised and fixed with $10 \%$ formaldehyde. Thrombosis-induced death of animals treated with $5 \% \mathrm{FeCl}_{3}$ solution was recorded after $24 \mathrm{~h}$.

Inflammation. Vascular permeability was tested using Pontamine skyblue as described $^{26}$. PGs alone, bradykinin alone, or both were intradermally injected. After $40 \mathrm{~min}$, mice were killed. The exuded dye in the skin was extracted and the amounts determined. Permeability was expressed as a percentage of that induced by $10 \mathrm{nmol}$ bradykinin alone in the same animals. Carrageenininduced pleurisy was evoked by injecting $40 \mu \mathrm{l}$ of $2 \%$ carrageenin into the right pleural cavity of mice ${ }^{14}$. After $3 \mathrm{~h}$, they were killed and the exudate volume measured.

Nociceptive tests. The tail-flick response was evoked either by heat ${ }^{18}$ or by applying pressure ${ }^{19}$. Latencies were determined by using a tail-flick apparatus (Ugo Basile) and with an analgesy meter (Ugo Basile), respectively. In the hotplate test, mice were placed on a plate $\left(55 \pm 0.1{ }^{\circ} \mathrm{C}\right)$ and the latency for jumping determined as described ${ }^{18}$. In the writhing test ${ }^{20}$, mice were intraperitoneally injected with either $0.9 \%$ acetic acid $\left(5 \mathrm{ml} \mathrm{kg}^{-1}\right)$ or PGs $(2 \mu \mathrm{g})$. The frequency of stretch responses was counted for $30 \mathrm{~min}$ for acetic acid or for $15 \mathrm{~min}$ for PGs. Indomethacin $\left(10 \mathrm{mg} \mathrm{kg}^{-1}\right)$ was administered intraperitoneally $30 \mathrm{~min}$ before acetic acid injection.

Data analysis. Data are expressed as means \pm s.e.m.. The significance of difference between groups was evaluated using ANOVA with a subsequent Dunnett's test, except for thrombus formation (Fig. 2 legend).

\section{Received 28 February; accepted 4 June 1997}

1. Campbell, W. B. \& Halushka, P. V. in The Pharmacological Basis of Therapeutics (9th edn) (ed Hardman, J. G. et al.) 601-616 (McGraw-Hill, New York, 1996)

2. Bunting, S., Moncada, S. \& Vane, J. R. The prostacyclin-thromboxane $A_{2}$ balance: pathophysiological and therapeutic implications. Br. Med. Bull. 39, 271-276 (1983).

3. Davies, P., Bailey, P. J., Goldenberg, M. M. \& Ford-Hutchinson, A. W. The role of arachidonic acid oxygenation products in pain and inflammation. Annu. Rev. Immunol. 2, 335-357 (1984).

4. Ushikubi, F., Hirata, M. \& Narumiya, S. Molecular biology of prostanoid receptors: an overview. J. Lip. Mediat. 12, 343-359 (1995)

Namba, T. et al. cDNA cloning of a mouse prostacyclin receptor. J. Biol. Chem. 269, 9986-9992 (1994)

6. Morham, S. G. et al. Prostaglandin synthase 2 gene disruption causes severe renal pathology in the mouse. Cell 83, 473-482 (1995).

7. Armstrong, R. A. et al. Fucntional and ligand binding studies suggest heterogeneity of platelet prostacyclin receptor. Br. J. Pharmacol. 97, 657-668 (1989).

8. Murata, T. et al. General pharmacology of beraprost sodium: Effect on the autonomic, cardiovascular and gastrointestinal systems, and other effects. Arzneim. Forsch. 39, 867-876 (1989).

9. Huang, P. L. et al. Hypertension in mice lacking the gene for endothelial nitric oxide synthase. Nature 377, 239-242 (1995).

10. Kurz, K. D., Main, B. W. \& Sandusky, G. E. Rat model of arterial thrombosis induced by ferric chloride Thromb. Res. 60, 269-280 (1990).

11. Vadas, P., Wasi, S., Movat, H. Z. \& Hay, J. B. Extracellular phospholipase $A_{2}$ mediates inflammatory hyperaemia. Nature 293, 583-585 (1981)

12. Ferreira, S. H. Inflammatory pain, prostaglandin hyperalgesia and the development of peripheral analgesics. Trends Pharmacol. Sci. 2, 183-186 (1981).

13. Winter, C. A. \& Flataker, L. Reaction thresholds to pressure in edematous hindpaws of rats and responses to analgesic drugs. J. Pharmacol. Exp. Ther. 150, 165-171 (1965).
4. Utsunomiya, I., Nagai, S. \& Oh-ishi, S. Differential effects of indomethacin and dexamethasone on cytokine produciton in carrageenin-induced rat pleurisy. Eur. J. Pharmacol. 252, 213-218 (1994).

15. Oida, H. et al. In situ hybridization studies of prostacyclin receptor mRNA expression in various mouse organs. Br. J. Pharmacol. 116, 2828-2837 (1995).

16. Malmberg, A. B. \& Yaksh, T. L. Hyperalgesia mediated by spinal glutamate or substance P receptor blocked by spinal cyclooxygenase inhibition. Science 257, 1276-1279 (1992).

17. Oka, T., Aou, S. \& Hori, T. Intracerebroventricular injection of interleukin- $1 \beta$ induces hyperalgesia in rats. Brain Res. 624, 61-68 (1993).

18. Piercey, M. F. \& Schroeder, L. A. Spinal and supraspinal sites for morphine and nefopam analgesia in the mouse. Eur. J. Pharmacol. 74, 135-140 (1981).

19. Millan, M. J. \& Colpaert, F. C. 5-Hydroxytryptamine (5-HT) ${ }_{1 \mathrm{~A}}$ receptors and the tail-flick response. II. High efficacy $5-\mathrm{HT}_{1 \mathrm{~A}}$ agonists attenuate morphine-induced antinociception in mice in a competitivelike manner. J. Pharmacol. Exp. Ther. 256, 983-992 (1991).

20. Koster, R., Anderson, M. \& deBeer, E. J. Acetic acid for analgesic screening. Fed. Proc. 18, 412 (1959). FINAL PAGE?

21. Doherty, N. S. et al. The role of prostaglandins in the nociceptive response induced by intraperitoneal injection of zymosan in mice. Br. J. Pharmacol. 91, 39-47 (1987).

22. Vane, J. R., Anggard, E. E. \& Botting, R. M. Regulatory functions of the vascular endothelium. New Eng. J. Med. 323, 27-36 (1990).

23. Kawabe, T. et al. The immune responses in CD40-deficient mice: impaired immunoglobulin class switching and germinal center formation. Immunity 1, 167-178 (1994).

24. Dejana, E., Callioni, A., Quintana, A. \& Gaetano, G. Bleeding time in laboratory animals. II-A comparison of different assay conditions in rats. Thromb. Res. 15, 191-197 (1979).

25. Ritter, J. M., Aksoy, A., Cragoe, E. J. \& Taylor, G. W. Actions of amiloride analogues on prostacyclin synthesis by rat aortic rings. Br. J. Pharmacol. 92, 857-862 (1987).

26. Ueno, A., Tokumasu, T., Naraba, H. \& Oh-ishi, S. Involvement of bradykinin in endotoxin-induced vascular permeabiity increase in the skin of rats. Eur. J. Pharmacol. 284, 211-214 (1995).

Acknowledgements. We thank K. Ishikawa and Y. Kataoka for ES cell injeciton and K. Okuyama for secretarial assistance. This work was supported by grants from the Ministry of Education, Science and Culture of Japan, the Japanese Society for Promotion of Sciences, the Uehara Memorial Foundation, the Smoking Research Foundation and the Japanese Foundation on Metabolism and Diseases.

Correspondence and requests for materials should be addressed to S.N. (e-mail: snaru@mfour. med.kyoto-u.ac.jp).

\section{Crustacean appendage evolution associated with changes in Hox gene expression}

\author{
Michalis Averof* \& Nipam H. Patel $\dagger$
}

Wellcome/CRC Institute, Tennis Court Road, Cambridge CB2 1QR, UK

$\dagger$ HHMI, University of Chicago, MC1028, N-101, 5841 South Maryland Avenue, Chicago, Illinois 60637, USA

* Present address: EMBL, Meyerhofstrasse 1, 69117 Heidelberg, Germany

Homeotic (Hox) genes specify the differential identity of segments along the body axis of insects. Changes in the segmental organization of arthropod bodies may therefore be driven by changes in the function of Hox genes ${ }^{1-3}$, but so far this has been difficult to demonstrate. We show here that changes in the expression pattern of the Hox genes $U b x$ and $A b d A$ in different crustaceans correlate well with the modification of their anterior thoracic limbs into feeding appendages (maxillipeds). Our observations provide direct evidence that major morphological changes in arthropod body plans are associated with changes in Hox gene regulation. They suggest that homeotic changes ${ }^{1,4}$ may play a role in the normal process of adaptive evolutionary change.

Genetic manipulation of model organisms like Drosophila can reveal the potential of developmental systems to undergo particular types of morphological change: for example, patterns of segmental specialization may be altered by changing the function of Hox genes. This approach alone, however, cannot identify the actual genetic changes that take place over macro-evolutionary timescales. Comparative studies are required but these so far indicate that crustaceans and insects share almost identical complements of Hox genes ${ }^{5}$ and that the domains of Hox gene expression have been broadly conserved during insect evolution (reviewed in ref. 6). Initial comparisons of Hox gene expression between crustaceans and insects documented changes associated with the independent specialization of trunk regions (thorax and abdomen) in these 